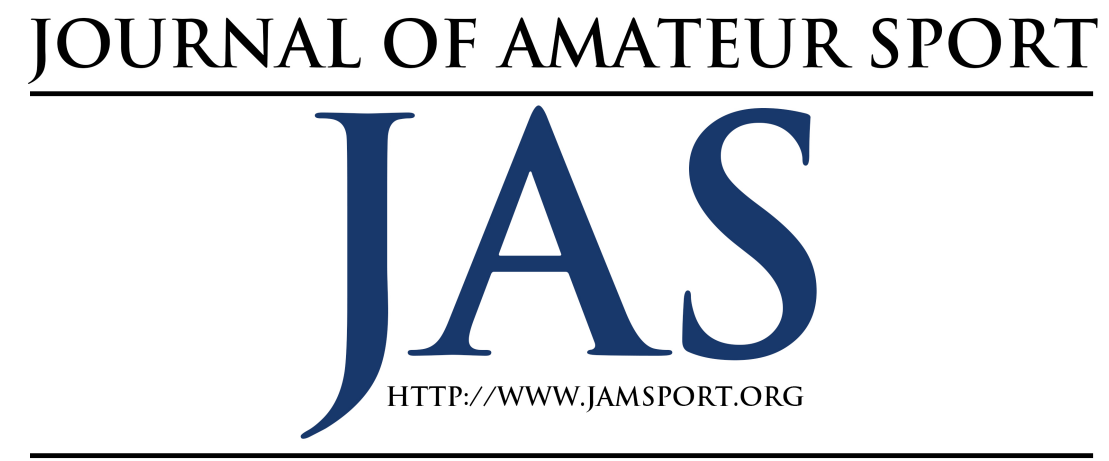

\title{
An Examination of Equal Access in Athletic Programs Throughout Public High Schools in the United States
}

\author{
Rebecca R. Buchanan ${ }^{1}$ \\ Eleanor Odenheimer ${ }^{2}$ \\ Tanya R. Prewitt-White ${ }^{3}$ \\ ${ }^{1}$ Emory \& Henry College \\ ${ }^{2}$ Southern Methodist University \\ ${ }^{3}$ Adler University
}

\begin{abstract}
The mission of the U.S. Department of Education is "to promote student achievement and preparation for global competitiveness by fostering educational excellence and ensuring equal access" (www.ed.gov). As an extension of U.S. public education institutions, secondary afterschool programs involving physical activity are theoretically designed to enhance and support the educational mission of public schools. Yet, due to the hyper-commodification of youth sports, "equal access" in sport and physical activity is becoming increasingly limited to parameters grounded in highly competitive environments reflecting broader sport trends in society. An interesting paradox emerges in public school settings where the importance of physical activity for adolescents is also emphasized. However, in reality, the majority of public tax dollars funding extracurricular opportunities to be physically active are only for those who are highly competitive, physically literate and have the financial means to assist in the funding of their sport experiences. There are also issues related to gender in terms of who is being served. Therefore, it is important to examine how public resources relating to physical activity and health are being unequally allocated in the public school setting.
\end{abstract}

$\mathrm{T}$ he mission of the U.S. Department of Education is "to promote student achievement and preparation for global competitiveness by fostering educational excellence and ensuring equal access" (www.ed.gov). As an extension of U.S. public education institutions, secondary afterschool programs involving physical activity are theoretically designed to enhance and support the educational mission of 
public schools. Yet, due to the hypercommodification of youth sports, "equal access" in sport and physical activity is becoming increasingly limited to parameters grounded in highly competitive environments reflecting broader sport trends in society. An interesting paradox emerges in public school settings where the importance of physical activity for adolescents is also emphasized. However, in reality, the majority of public tax dollars funding extracurricular opportunities to be physically active are only for those who are highly competitive, physically literate and have the financial means to assist in the funding of their sport experiences. There are also issues related to gender in terms of who is being served. For example, in Virginia during the 2012-13 academic year, only $40 \%$ of females participated in high school athletics (NFSHSA, 2015; NCES, 2015). The rates of participation are even lower among Black and Latina females as well as those from low-SES families (Johnston, Delva, \& O’Malley, 2007).

Therefore, we argue that it is important to examine how public resources relating to physical activity and health are being unequally allocated in the public school setting. For the purposes of this article, we will focus on gender inequity within high school athletic programs. To contextualize the current issue, we discuss a brief history of sport and physical education in the United States, while focusing on the commercialization of youth sport. As such, the hyper-commodification of sport results in a gendered, political economy within the sporting landscape. We center our discussion on the nexus of economy, sport, access, and gender.

\section{A "Brief" History}

An old cliché states that you can't understand the future unless you understand the past. This cliché has relevance to public education in the United States in relation to how sport and physical education became embedded as part of the educational process. High school sports initially began as a student led initiative to create opportunities for participation. As interscholastic sports evolved into a more adult-directed and controlled experience, the original mission and purpose focused on promoting "pure amateur sport", which supported the educational mission of schools (NFHS, 2015b). Yet the rapid and intensified commercialization of sport in advanced capitalist societies has permeated educational institutions to the point that engagement in sport often results in a hyper-commodified experience in which the teams and athletes are viewed as commercial products to be packaged and promoted. This section provides a brief overview of this process beginning with the nineteenth century.

As a result of industrialization, organized youth sports grew exponentially between 1880 and 1920 (Rader, 2009). This growth was due in large part to concerns that young males were no longer being involved in productive work and moral 
development at home or through apprenticeships (Mechikoff, 2013). As more items became available for purchase in the marketplace, there was less interaction between young males and their fathers in urban settings where many fathers began working away from home. Of similar concern was the lack of apprenticeship, vocational-based opportunities that declined as a result of societal reliance on machinery. During this time, laws were passed which extended the length of the school term from four months to nine months and impacted the age at which adolescents should attend school and enter the work force (14 and older) (Rader, 2009). In addition, there was a push by middle- and upper-class parents for their children to further their educations to secure white-collar professions such as doctors and lawyers. As a result of these changes, youth spent more time with their peers in spaces unsupervised by adults. Of additional concern was the ways in which males could continue to maintain a strong, physical, and aggressive presence in an increasingly industrialized nation in which physical dominance was not necessitated.

After the Civil War, the Young Men's Christian Association (YMCA) offered classes in gymnastics and calisthenics to generate interest among young men and to encourage males in their spiritual journeys (Lumpkin, 2011). As part of the "muscular Christianity" movement, Luther Halsey Gulick Jr. stressed the foundation of a strong spiritual life was grounded in the uniform development of both mind and body (Wuest \& Fisette, 2015). Eventually, competitive athletic competitions resembling modern day sport grew in popularity and number. Justification for sport participation throughout the nineteenth century included values surrounding the benefits of competitiveness, health, manliness, and strength/power as related to religion (Anderson, 2010).

At the same time that youth sport was increasing in popularity, the field of physical education began to evolve. As an academic field in higher education, there were ongoing discussions regarding the pros and cons of Swedish vs. German gymnastics (Wuest \& Fisette, 2015). During this time, professionals were also debating the calisthenics system developed by Catherine Beecher. Discussions involved medical professionals as well as physical educators as they struggled to develop a solid theoretical framework specific to physical education (Mechikoff, 2013).

According to Anderson (2010), the first interscholastic sports in public high schools were actually student-led and directed. Toward the end of the $19^{\text {th }}$ century into the $20^{\text {th }}$ century, students formed the first athletic associations as well as managed all administrative aspects of competition such as game schedules and finances. As football grew in popularity and a "win at all cost mentality" took root, undesirable student outcomes, such as a loss of academic focus, and unethical behaviors, such as the "use of 'ineligible' players," resulted (Rader, 2009, p. 
114). In 1920, educators created the Midwest Federation of State High School Athletic Associations (MFSHSA) to provide parameters and authority over interscholastic sports. Specifically, the purpose of the association was "to protect the athletic interests of high schools belonging to the various state associations and to promote pure amateur sport" (NFHS, 2015b, p. 18). In 1923, this organization was renamed to its current name, the National Federation of State High School Athletic Associations (NFHS, 2015b).

The "comprehensive" secondary school ideology evolved into an experience that continued to emphasize academics. However, vocational knowledge was also emphasized in addition to social values. Many leaders and social educators subscribed to the notion that extracurricular activities such as sports could teach social values and also serve as a means to manage student behaviors. Additionally, educators also believed that an esprit de corps could result in a more cohesive student body and community as a whole. While social educators touted the benefits in relation to social development and a sport-for-all philosophy, school boards and communities formed an ideology focused more on the development of strong varsity programs. Along with the expansion of competitive varsity programs, increases in the intensified market relations in sport have led to a hyper-commodification of youth sports
(Walsh \& Giulianotti, 2007). This concept is discussed in the next section.

\section{Hyper-Commodification of Youth Sports}

Over the past few decades, there has been a shifting cultural emphasis on sport in society. This emphasis, largely focused on professional sports, has permeated institutions of higher education as well as public high schools. Many would argue that as a result, educational priorities have been compromised as sporting endeavors generate more publicity and revenue. According to DeSensi (2014),

The current status of intercollegiate athletics has experienced a transformation in the role it appears to have played throughout history to the present time. The educational value of developing the body, mind, and spirit of students, has been transformed into campus, state, regional, national, and global entertainment, money making ventures, and spectacles. (p. 59)

The authors, along with others, argue that the emphasis now placed on professional as well as collegiate sports has compromised the mission and value of sports in public high schools throughout the United States (Budig, 2007). According to DeSensi and Rosenberg (2010), school and community sports are more than ever before being modeled after professional sports where athletes have become important commodities. Yet, in contrast to professional sports, school and community 
sports are considered "amateur" and involve "those who participate and govern at the youth, recreational, community, international, and intercollegiate level" (Journal of Amateur Sport, n.d., para. 1).

As one considers aspects relating to hyper-commodification, it is important to distinguish similarities and differences of this term as related to commodification. According to Giulianotti (2015), "commodification" can be described as the "process by which an object or social practice acquires an exchange value or market-centered meaning" (p. 250). A similar definition states that commodification is "the transformation of a thing with only use-value to a good with both use-value and exchange-value" (Walsh \& Giulianotti, 2007, p. 12). From a more critical viewpoint, commodification in sport can also refer to social structures in which "the individual is viewed and treated as an object to be manipulated, bought, and sold" (DeSensi \& Rosenberg, 2010, p. 13). For those who subscribe to a philosophy of amateurism, commodification in sport is problematic because it compromises goals such as the pursuit of excellence and the intrinsic value derived as a result (Walsh \& Giulianotti, 2007, p. 14).

Although some may argue that commodification and the exchange-value in sport has always existed, Walsh and Giulianotti (2007) argue that the term "hyper-commodification" provides a more accurate description of modern sport. The term "hyper-commodification" can be defined as "both the substantive increase in the range and number of goods that are bought and sold as well as the intensification of market understandings and attitudes towards sport itself' (Walsh \& Giulianotti, 2007, p. 14). There are four main concepts related to this term:

1) The transformation of clubs and systems into corporations,

2) The emergence of large numbers of highly paid sportspeople,

3) The advent of large scale advertising and merchandising in sport, and

4) The 'venalisation' of the ethos of sport

(Walsh \& Giulianotti, 2007, p. 14) The first concept, "the transformation of clubs and systems into corporations", revolves around a sporting industry in which the moral atmosphere has shifted to a concern with profits over any other considerations (Walsh \& Giulianotti, 2007, p. 14). Impersonal, corporate entities of power, often on a globalized scale, have replaced what were once local community clubs and organizations. The involvement of wealthy investors as well as media corporations provides an additional layer of influence in relation to the hypercommodification process. The connection with this concept begins long before students enter high school. The emergence of professional training facilities and yearround travel teams for youth is indicative of a shift in which adult-directed athletic endeavors have a targeted financial goal in mind. The targeted financial goal for year- 
round travel teams is a college scholarship for the athletes, which in turn benefits parents. This goal also provides credibility for coaches in relation to fees charged for their services. The targeted financial goal for professional training facilities, such as indoor batting cages, is ensuring a consistent revenue stream through encouraging year-round participation. Interestingly, the single sport year-round model does not align with research indicating that there are greater benefits to diversification (Lumpkin, 2011).

The next aspect to consider is the "emergence of large numbers of highly paid sportspeople" (Walsh \& Guilianotti, 2007, p. 14). Prior to the 1960 s, athletes were often loyal to the communities and teams they represented and vice versa. However, the professionalization of sport has led to a breakdown of this loyalty in all respects.

Interestingly, a similar phenomenon has also happened with students participating in high school sports. Instead of being loyal to the communities and teams where they attended elementary and middle school, some high school athletes move to a rival school with the rationale that the athletic program (not academics) is better (Sondheimer, 2014). Their rationale is often based on the premise that to earn a Division I scholarship, they must attend the school with the best athletic program and coaching staff. Similar concerns are also evident in regards to loyalty of athletes and their families to club / AAU / travel teams over their high school teams ("What effect,"
2014). Young athletes are learning and being told that college coaches are not going to their high school games because the coaches will have to wade through the talent. Instead, they are most likely to recruit at larger venues such as AAU basketball tournaments, legion baseball and tennis open tournaments where the talent is more plentiful (Drotar, 2015). The issue is complex in that many of the privatized programs require an even greater financial and time investment than required of high school programs. Therefore, many parents want to take full advantage of their investment. The result in terms of a lack of equal access is two-fold. First, athletes whose families have financial capital to pay for more specialized coaching and training expertise are more likely to earn positions on their high school teams instead of being cut. Secondly, the result is a reproduction in high school sports of economic inequalities evident in larger society (Lumpkin, 2011).

The third aspect relates to "the advent of large scale advertising and merchandising in sport" (Walsh \& Guilianotti, 2007, p. 14). From stadium fences to game broadcasts, marketing, advertising, and merchandising are a core component of modern sport. Although a mainstay for professional sports, merchandising opportunities in high school sports have been explored with a mixture of positives and negatives. As educational funding continues to be reduced, many high school athletic programs are actively seeking solutions to the funding deficits. One option is merchandise sponsorship through 
companies such as Under Armour and Nike. This option can provide substantial funds and discounts for athletic equipment and is considered a standard practice in states such as California (Donaldson, 2013). However, the result in some areas is a "keeping up with the Jones" mentality in athletic equipment and apparel where schools feel pressure to provide the same high standard of quality as other schools in their area.

There is also additional pressure related to the contract in which the overall win-loss record in high school becomes paramount to continuing a contract with a particular apparel company. For those amateur athletes who become professional, sponsorship agreements can also be problematic. When athletes are contractually obligated to a particular company, they may have less control over their competition schedules and other aspects of their lives. This aligns with earlier definitions of commodification in sport where individuals become objectified in the quest for financial gain (DeSensi \& Rosenberg, 2010).

The final aspect of hypercommodification is "the 'venalisation' of the ethos of sport" (Walsh \& Giulianotti, 2007, p. 14). Venalisation refers to a mindset where money is the central focus and predominates all other considerations. "All other considerations" include a lack of concern for student-athletes. For example, some media companies are attempting to negotiate contracts to develop and televise high school football playoff games
(Sepulvado, 2014). In Florida, each team would receive $\$ 12,500$ as an appearance fee and another $\$ 25,000$ in merchandising fees. However, some are concerned that this would exploit the young athletes at a vulnerable time in their development.

In summary, this section has outlined the shifting emphasis of sport in society as related to hyper-commodification. This shift has not only impacted professional sports, but also collegiate and high school sports. The next section outlines participation numbers and issues related to participation (or lack of).

\section{Equal Access}

As referenced earlier, the U.S. Department of Education's mission is “to promote student achievement and preparation for global competitiveness by fostering educational excellence and ensuring equal access" (www.ed.gov). Afterschool programs at public schools are provided as an extension of the educational mission and therefore should provide equal access. Yet, an examination of $9^{\text {th }}-12^{\text {th }}$ grade athletic participation rates throughout public schools in the United States indicate that in every state and the District of Columbia, the rates are lower for females than males (Table 1) (NCES, 2015; NFHS, 2015a) and in over half the states, female participation rates are less than fifty percent. A further understanding regarding how the participation numbers are calculated reveals even more imbalance. Participation numbers are even less than indicated in 
Table 1 because student-athletes who play multiple sports are counted more than once. Therefore, one individual could be counted three times if he or she played three sports during the academic year. Even more concerning are data indicating that certain demographic subgroups of females engage in lower rates of physical activity. Overall, ethnic minority females are less active than white females (Staurowsky et al., 2015). Latina females, the fastest growing female ethnic minority group in the U.S., engage in less physical activity than any other major demographic subgroup (Larsen, Pekmezi, Marquez, Benitez, \& Marcus, 2013).

Another way to approach equal access is in terms of outcomes associated with the sporting experience. Are all students afforded equal access to a variety of outcomes other than just the win-loss record or the type of sports in which they participate? One important aspect to consider in relation to female involvement in sport and physical activity is how females interpret their experiences and the meanings they derive as a result. This interpretive process can greatly influence student choice as related to their involvement (or lack of) in sports.

The overall quality of the experience can be diminished when there are "outcome discrepancies” (Buchanan, 2011, p. 108). Outcome discrepancies refer to "the intended or preferred outcomes of participants as compared to the teacher, coach, or other individuals in positions of power" (p. 108). Research by Cooky (2009) illustrates this point in relation to sporting opportunities for females. There is an abundance of sporting opportunities available for females in comparison to availability prior to Title IX. However, Cooky (2009) points out that although the number of opportunities has risen significantly, the outcomes related to participation are still linked with ideologies situated within competition and dominance. Yet many females (and some males) prefer an "atmosphere of cooperation in which everyone achieves a common goal" as opposed to "an atmosphere in which the success of some is dependent upon the failure of others" (Buchanan, 2011, p. 25).

According to Staurowsky et al. (2015), the enthusiasm exhibited by high school females in physical education was dependent upon the types of offerings. For example, many preferred fitness-based physical activity as opposed to sport units. The rationale provided included an emphasis on health, fun, and something they could do beyond school. Research findings from the Tucker Center for Research on Girls and Women in Sport found similar findings in that the most prevalent reason girls give for participating in sport is having fun (Kane \& LaVoi, 2007). These experiences mirror a "pleasure and participation" sport model as opposed to a "power and performance" model (Coakley, 2015, p. 686). The power and performance sport model, which encourages competition and dominance, has historically been the most popular form of 
sport in the United States and appeals to those in positions of wealth and power. In contrast, pleasure and participation sporting models are not as often supported when compared to power and performance models (Buchanan, 2011). This section has outlined issues with equal access as related to participation numbers and varying experiences in terms of the overall outcome. The next section continues this discussion in relation to economic and financial capital.

\section{Financial / Social Capital}

The hyper-commodification of professional and college sport has trickled down into school sport to the point that it is becoming an extracurricular option mainly for those with financial and social capital. As Odenheimer (2012) stated, "economic or financial capital refers to monetary assets and income. Socio-economic position partly determines a person's economic capital (Bourdieu, 1984) and thus what sports they, or their children, have access to" (p. 8). That is to say, the amount of wealth and economic capital a person has impacts the type of sports (e.g. sailing vs. running) someone engages in and at what level of participation (e.g. local vs. international). Odenheimer (2012) went on to explain that, "people use their economic capital to accumulate other forms of capital, namely social and cultural" (p. 8) and "in simplest terms, social capital refers to one's social network or social relationships, formal or informal, with other people, groups, or organizations (Bourdieu, 1984)" (as cited in Odenheimer, 2012, p. 11).

In athletic programs, social capital could refer to the type of sport a person chooses based on his or her existing social relationships. There are four aspects relating to financial and social capital included in this discussion. Those aspects relate to 1) athletic equipment, mileage, and gate fees, 2) health insurance, 3) fundraising, and 4) alternate activities.

In terms of financial capital, there are various costs associated with athletic equipment. The following numbers and information are based off expenditures of one author whose son is currently playing high school football. The initial costs associated with playing football at a high school in a rural area of Virginia includes the following: $\$ 80$ for football cleats and $\$ 55$ for a Spirit Pack which included shorts and a $t$-shirt required for two-a-day practices. During the parent meeting, the coach did point out that parents could touch base with him in the event they were unable to pay for the Spirit Pack. Prior to the season beginning, there were also mileage costs related to summer practices which athletes were expected to attend. Once the season starts, there are mileage costs related to driving to/from the school on a daily basis to pick up students after practice. Additionally, the cost to attend games ranges from $\$ 5-\$ 6 /$ person, including children. Therefore, a family of five would pay $\$ 20$ - $\$ 24$ / week to support their son or daughter. Throughout the 
course of a month, the cost would be $\$ 80$ $\$ 96$ per month. If he or she was involved in basketball or volleyball, there are often two games per week which would then result in \$160-192 / month. This does not include costs associated with more than one child participating or driving to/from the home school and/or away games. Granted, families do not have to attend each game. Yet as indicated above, social capital includes those in one's social networks. As such, part of the modern-day era of parenting for many middle and upper-class families is that parents feel obligated to support their children as "good" parents by being highly involved in all aspects of their sport participation, including being present for competitions, which is a physical expression of social capital (Coakley, 2015).

The second aspect of financial inequality is related to health insurance. An HBO Real Sports episode recently highlighted collegiate student-athletes and the medical bills they acquired as a result of injuries sustained in their respective sports (Real Sports, 2015). It is understood that injuries can occur at any point throughout the season. However, similar to the concept of worker's compensation, many assume that an injury an athlete sustains as part of his or her school-sponsored involvement would be covered by the respective school system. Yet further examination reveals that this coverage is very limited in high school.

According to one high school student athletic handbook, there is a $\$ 10,000$ maximum benefit to cover athletic injuries and the coverage would be secondary to any other insurance (WCPS, 2015). Of the various injuries which can occur, knee injuries rank among one of the most common. The cost for a knee injury requiring ACL surgery and rehabilitation can be up to $\$ 17,000$ (Frisch, Croisier, Urhausen, Seil, \& Theisen, 2009). Therefore, the cost for a family without insurance other than what is provided through the school would be $\$ 7,000$. If a family has a high deductible insurance plan, they could be responsible for the first $\$ 10,000-\$ 12,000$, depending on the plan. Interestingly, on the same page that outlines insurance coverage, the student athletic handbook also states "there is a risk of serious injury which may result from athletic participation" (WCPS, 2015, p. 3).

Due to concerns relating to sport injuries, those who lack good health insurance may be better off by participating in non-contact activities such as aerobics and walking (Coakley, 2015), which connects back to the concept of economic capital and its impact on sport choice. However, many schools do not provide funding for extracurricular options such as these. The result is that children who are not as socioeconomically advantaged are not afforded opportunities to participate in any type of extracurricular physical activity, whether traditional sports or non-contact activities.

The third aspect of financial inequality is related to various fundraisers conducted to raise money for the athletic program. In 
the county where one author's child attends high school, discount cards to local restaurants are currently used as a main fundraiser for various sports such as football and baseball. Athletes are asked to sell 20 cards at a cost of $\$ 20$ per card. The assumption by school administrators, athletic directors, and coaches is that student-athletes have enough social capital in relation to one's social networks or social relationships to sell the cards. In some instances, student-athletes are encouraged to sell a specified number of cards by a certain date in order to be excused from a portion of the physical conditioning session. This is problematic in that it mirrors the common practice in some sports of directing students to run as a type of punishment when they fail to perform adequately in either practice or competition.

Yet in this particular instance, a lack of acceptable performance is linked to issues relating to socioeconomic status and social capital. In terms of hyper-commodification, this represents the venalisation of sport in which money supersedes all other considerations (Walsh \& Guilianotti, 2007). Another issue specific to the card fundraiser is the focus on advertising and promotion of eating at fast food restaurants. Along with associated costs of eating out, most cards include discounts to dining establishments with limited healthy options.

According to the Center for Science in the Public Interest (2007), "school-based marketing adds credibility to marketing efforts by associating a company's name, brands, or products with schools and teachers [or coaches], which are trusted institutions and role models for children" (p. 3). Advertising and promoting fast food directly contradicts school wellness policies which limit fast foods being brought into the schools. This represents yet another example of how advertising and merchandising in sport on a large scale has permeated the amateur environment of high school athletics.

The fourth financial aspect to consider is the type of extracurricular opportunities that may appeal to females. Many of the most popular physical activities for females are not offered through public school systems and are limited to families with financial resources. Due to the emphasis on traditional competitive sports, afterschool opportunities to be physically active such as ballet, yoga, dance, gymnastics, archery, etc. are usually not offered. Interestingly, these are also forms of physical activity in which females are often equal to or more physically literate than males.

According to Whitehead (2010), a physically literate individual possesses the "motivation, confidence, physical competence, knowledge and understanding to maintain physical activity throughout the lifecourse" (p. 5). This definition expands what is often considered athletic competence limited to traditional sports. For example, Buchanan (2011) found that male students in a high school physical education class which included nontraditional sports were surprised to find that 
females in the class were often equally or more competent in certain sports such as archery. Yet involvement in these types of activities often require financial capital as well as social capital and are not currently offered as extracurricular options at most public high schools throughout the United States. When alternate programs are offered, instructors often volunteer their time or seek alternate ways of receiving compensation such as through grants or sponsorships.

The inequalities included in this section are directly influenced by the power and performance ideology which "explains and justifies economic inequalities as part of the natural order of things" (Coakley, 2015, p. 66). Broader than actual sport participation, many dominant political ideologies are reproduced through sport. Just as much of the U.S. political arena is influenced by money, so too are high school sports. Those who have more financial capital have greater access and influence than those who do not. For example, a recent analysis of high school athletics in North Carolina found that the number of state championships was higher in schools with lower free and reduced lunch percentages (Stevens, 2015). The meritocratic ideology often goes unquestioned and results in less participation by those with financial limitations. The next section offers insight into an interesting paradox in public schools regarding sport participation vs. physical activity.

\section{The Paradox of Sport Participation vs. Physical Activity (Why It Matters)}

There is a plethora of research available regarding the benefits of physical activity (Bocarro et al., 2014; Pangrazi \& Beighle, 2010; Ratey, 2008). Specifically for females, a physically active lifestyle can lower the risk of breast cancer, illicit drug use, and depression (Staurowsky et al., 2015). Yet a recent report released by the Women's Sports Foundation indicates that in the United States, only $25 \%$ of females age eleven and under are getting the recommended levels of physical activity (Staurowsky et al., 2015). According to the Centers for Disease Control and Prevention (CDC) (2015), youth ages 6-17 should have 60 minutes of physical activity each day. Yet by age 15 , levels of physical activity drop to $17 \%$. This trend is continuing even though required health and physical education classes stress the importance of physical activity on a regular basis. Recent research also indicates that along with health benefits, physical activity provides significant neurological benefits, which can positively impact the learning process (IOM, 2013; Ratey, 2008). According to the Institute of Medicine (2013), incorporating physical activity throughout the school day can influence the success of academic endeavors. Pontifex et al. (2013) also found that moderate-intensity aerobic exercise positively impacts students diagnosed with ADHD, which contributes to their on-task behavior and academic success in the classroom. 
Due to research regarding the importance of physical activity, federal legislation was passed to support initiatives in public schools. For example, as a result of the Child Nutrition and WIC (Women, Infants, and Children) Reauthorization Act of 2004, all U.S. school districts receiving federal funding for school meals were required to develop and implement comprehensive wellness policies (Pangrazi $\&$ Beighle, 2010). The policies were to be approved and in place by the 2006-2007 academic year and were specifically designed to address nutrition and physical activity. Although many schools included references to a range of opportunities to be physically active, the majority still relies on traditional sports programs as a way to comply with the federal legislation. For example, one county's wellness policy states "students shall be given opportunities for physical activity through a range of after-school programs" (Wellness program, n.d., p. 10). Yet the after school programs involving physical activity at the high school level are limited solely to the competitive sports teams. As a result, public funding is being used for coaches and predominantly male students who are more physically literate in traditional sports than their peers.

This continuing trend is disturbing given the benefits of physical activity, regardless of the competitive or noncompetitive nature of the activity. Herein lies the paradox. As referenced earlier, competitive sport brings the inherent risk of injury that can range from mild to severe.
Athletes are often asked to follow the "no pain, no gain" philosophy to win at all costs. However, research indicates that the healthiest types of physical activity are noncompetitive and rhythmic (Buchanan, 2011).

Another paradox arises when considering intramural sports offerings in relation to varsity sports. In contrast to interscholastic varsity sports, which limit participation and are highly competitive, intramural sports offer a more inclusive alternative. Research has indicated that schools with intramural sports programs and policies have higher student participation rates than those which offer only varsity sports (Drake et al., 2015; Kanters, Bocarro, Edwards, Casper, \& Floyd, 2013). The intramural sports model provides opportunities for students who may have lower levels of physical literacy which limit their opportunities to participate on varsity sport teams even though they still enjoy traditional sports such as basketball. The intramural sports model also provides options for students interested in athletic experiences beyond traditional competitive sports.

Yet intramural programs are often dependent upon a school's "size, budget, and geographic location" (Drake et al., 2015). There are obviously great benefits to those who participate in high school sports. However, if there are also benefits to being physically active unrelated to the competitive varsity sports model, then how can public schools continue to justify using 
public dollars to support only a small segment of the student population focused on a power and performance model?

\section{Conclusion}

Research regarding involvement in youth sport and physical activity highlights benefits derived as part of participation. Those benefits include improved selfconfidence and self-esteem (Wann, Belva, Armstrong, Weaver, \& Ladd, 2015). Directly related to academic endeavors are data indicating that there are significant neurological benefits specific to academic achievement when students are physically active (IOM, 2013; Ratey, 2009). Yet due to the hyper-commodification of sport, many students are not afforded equal access to physical activity in public high schools throughout the United States. According to Wiggins (2013), modern day youth sports have evolved into "a system that places more importance on winning than a sound educational experience" (p. 72). In a similar fashion, DeSensi and Rosenberg (2010) state

If a main program objective is to provide sport for all, then limitations on participation cannot be coherently and ethically sustained. Similarly, the types of activities offered, the quality of instruction and supervision, and the ways in which programs are funded fall within the realm of social responsibility. (p. 10)

Recommendations for change include providing funding to expand the current extracurricular offerings in public schools. The expansion should include consideration for varying levels of physical literacy, accommodating gender preferences for activities as well including types of experiences from broader, more diverse perspectives. For example, research has indicated that in some instances, students are more physically active in an intramural sport setting in contrast to an interscholastic sport setting (Bocarro, Kanters, Edwards, Casper, \& McKenzie, 2014). In efforts to enable sport to be a more inclusive space with learning and engagement of our youth as the paramount goal, the authors suggest considerations for program implementation which challenges the "win at all cost mentality." Suggestions include opportunities informed by child development research such as the Aspen Institute's Sport and Society Program Project Play (www.aspenprojectplay.org). Other suggestions include after school opportunities modeled after programs such as Girls on the Run (www.girlsontherun), Ready, Set, Run (www.nays.org), and GoGirlGo!

(www.womenssportsfoundation.org). Rather than focusing on winning, these programs provide a different type of experience in which physical activity is combined with an educational component or character-based curriculum. Given the plethora of benefits associated with a physically active lifestyle, a reconsideration of resources in the public school setting 
should be a priority in the realm of public education. 


\section{References}

Anderson, E. (2010). Sport, theory and social problems. New York, NY: Routledge.

Bocarro, J. N., Kanters, M. A., Edwards, M. B., Casper, J. M. \& McKenzie T. L. (2014). Prioritizing school intramural and interscholastic programs based on observed physical activity. American Journal of Health Promotion, 28(3), S65-S71.

Bourdieu, P. (1984). Distinction: A social critique of the judgment of taste.

Cambridge, MA: Harvard University Press.

Buchanan, R. R. (2011). The pleasure and participation sports model as reflected through an Advanced Physical Education course. (Doctoral dissertation). Retrieved from http://trace.tennessee.edu/utk_grad diss/1062.

Budig, G. A. (2007). An athletic arms race. Phi Delta Kappan, 89(4), 283284.Centers for Disease Control and Prevention. (2015). Youth physical activity guidelines. Retrieved from http:/ / www.cdc.gov/healthyschools /physicalactivity/guidelines.htm.

Center for Science in the Public Interest (2007). Sweet deals: School fundraising can be healthy and profitable. Retrieved from http://www.cspinet.org/ school fundraising.pdf.

Coakley, J. (2015). Sports in society: Issues and controversies (11th ed.). New York, NY: McGraw-Hill.
Cooky, C. (2009). “Girls just aren't interested": The social construction of interest in girls' sport. Sociological Perspectives, 52(2), 259-284.

DeSensi, J. T. (2014). Sport: An ethos based on values and servant leadership. Journal of Intercollegiate Sport, 7, 58-63.

DeSensi, J. T. \& Rosenberg, D. (2010). Ethics and morality in sport management ( $3^{\text {rd }}$ ed.). Morgantown, WV: West Virginia University.

Donaldson, A. (2013, March 5). High school sponsorship contracts raise concerns, but also benefit programs. Deseret News. Retrieved from http://www.deseret news.com.

Drake, K. M., Longacre, M. R., MacKenzie, T., Titus, L. J., Beach, M. L., Rundle, A. G., \& Dalton, M. A. (2015). High school sports programs differentially impact participation by sex. Journal of Sport and Health Science, 4, 282-288.

Drotar, B. (2015). The recruiting code: Deciphering the college selection process for the student athlete. New York, NY: Bryan Drotar.

Frisch, A., Croisier, J., Urhausen, A., Seil, R., \& Theisen, D. (2009). Injuries, risk factors and prevention initiatives in youth sport. British Medical Bulletin, 92, 95-121.

Giulianotti, R. (2015). Supporters, followers, fans, and Flâneurs: A taxonomy of spectator identities in football. In D. Karen, \& R. E. Washington, (Eds.), Sociological Perspectives on Sport (249262). New York, NY: Routledge. 
Institute of Medicine Report - Educating the Student Body: Taking Physical Activity and Physical Education to School (2013, May). Retrieved from http://www.iom.edu/Reports/2013/ Educating-the-Student-Body-TakingPhysical-Activity-and-PhysicalEducation-to-School.aspx).

Johnston, L. D., Delva, J., \& O’Malley, P. M. (2007). Sports participation and physical education in American secondary schools: Current levels and racial / ethnic and socioeconomic disparities. American Journal of Preventive Medicine, 33(4), S195-208. Journal of Amateur Sport. (n.d.). Mission and purpose. Retrieved from http://jamsport.org/mission.shtml.

Kane, M., \& LaVoi, N. (Eds.). (2007). The 2007 Tucker Center Research Report, developing physically active girls: An evidence-based multidisciplinary approach.

Minneapolis, MN: University of Minnesota.

Kanters, M. A., Bocarro, J. N., Edwards, M. B., Casper, J. M., \& Floyd, M. F. (2013). School sport participation under two school sport policies: Comparisons by race/ethnicity, gender, and socioeconomic status. Annual of Behavioral Medicine, 45(Suppl 1), S113-S121.

Larsen, B. A., Pekmezi, D., Marquez, B., Benitez, T. J., \& Marcus, B. H. (2013). Physical activity in Latinas: Social and environmental influences. Womens Health, 9(2), 201-210.
Lumpkin, A. (2011). Physical education, exercise science, and sport studies. New York, NY: McGraw Hill.

Mechikoff, R. (2013). A bistory and philosophy of sport and physical education. New York, NY: McGraw Hill.

National Center for Education Statistics (2015). Retrieved from http://nces.ed.gov/ccd/elsi.

National Federation of State High School Associations (2015a). 2012-13 High school athletics participation survey. Retrieved from http://www.nfhs.org/.

National Federation of State High School Associations (2015b). 2015-16 Handbook. Retrieved from https://www.nfhs.org/media/10158 24/2015-16-nfhs-handbook.pdf.

Odenheimer, E. (2012). Adaptations of yoga: Christian interpretations. (Doctoral dissertation). Received from http://trace.tennessee.edu/utk_grad diss $/ 1453 /$.

Pangrazi, R. P., \& Beighle, A. (2010). Dynamic physical education for elementary school children (16 ${ }^{\text {th }}$ ed.). San Francisco, CA: Pearson

Pontifex, M. B., Saliba, B. J., Raine, L. B., Picchietti, D. L., \& Hillman, C. H. (2013). Exercise improves behavioral, neurocognitive, and scholastic performance in children with attention-deficit / hyperactivity disorder. Journal of Pediatrics, 162, 543551. 
Rader, B. G. (2008). American sports: From the age of folk games to the age of televised sports (6th ed.). Upper Saddle River, NJ: Prentice Hall, Inc.

Ratey, J. J. (2008). SPARK: The revolutionary new science of exercise and the brain. New York, NY: Little, Brown and Company.

Real Sports. (2015, March 24). The wreckage. Retrieved from http://www.hbo.com/real-sportswith-bryant-gumbel/episodes/0/216episode/synopsis/march-on-realsports-with-bryant-gumbel.html.

Sondheimer, E. (2014, August 14). Unfortunately, changing schools is the norm for prep athletes. Los Angeles Times. Retrieved from http://www.latimes. com/ sports/highschool/la-sp-transferssondheimer-20140803-column.html.

Staurowsky, E. J., DeSousa, M. J., Miller, K. E., Sabo, D., Shakib, S., Theberge, N., Veliz, P., Weaver, A., \& Williams, N. (2015). Her Life Depends On It III: Sport, Physical Activity, and the Health and Well-Being of American Girls and Women. East Meadow, NY: Women's Sports Foundation.

Stevens, T. (2015, July 25). Analysis finds ties between wealth, winning in NC high school sports. The News and Observer. Retrieved from http://www.newsobserver. com/sports/highschool/article28720411.html
Sepulvado, J. (2014, October 17). In context: The big business of high school sports. Marketplace Economy. Retrieved from www.marketplace.org.

Walsh, A. \& Giulianotti, R. (2007). Ethics, money and sport. New York, NY:

Routledge.

Wann, D. L., Belva, B., Armstrong, S., Weaver, S., \& Ladd, S. (2015). Investigating the impact of team identification on the willingness to commit verbal and physical aggression by youth baseball spectators. Journal of Amateur Sport, 1(1), 1-28.

WCPS (2015). Student Athletic Handbook. Wellness program (n.d.) Retrieved from http://www.wcs.k12.va.us / sites/default/files/district/healthwe llness/regulations.pdf.

What effect do AAU/travel ball teams have on sport participation at the high school and middle school level? (2014). JOPHERD, 85(7), 46-47. Whitehead, M. (Ed.). (2010). Physical literacy: Throughout the lifecourse. New York, NY: Routledge.

Wiggins, D. K. (2013). A worthwhile effort? History of organized youth sport in the United States. Kinesiology Review, 2, 66-75.

Wuest, D. A. \& Fisette, J. L. (2015). Foundations of physical education, exercise science, and sport $\left(18^{\text {th }}\right.$ ed.). New York, NY: McGraw Hill. 
Table 1

\section{Tables}

\section{U.S. Public high school enrollment numbers and atbletic participation rates (2012-13)}

\begin{tabular}{|c|c|c|c|c|c|c|c|c|c|}
\hline State & $\begin{array}{l}\text { Total } \\
\text { Enrollment } \\
\text { Grades } \\
9-12\end{array}$ & $\begin{array}{c}\text { Total } \\
\text { Participation }\end{array}$ & Percent & $\begin{array}{c}\text { Male } \\
\text { Enrollment }\end{array}$ & $\begin{array}{l}\text { Male Sports } \\
\text { Participation }\end{array}$ & Percent & $\begin{array}{l}\text { Female } \\
\text { Enrollment }\end{array}$ & $\begin{array}{l}\text { Female Sports } \\
\text { Participation }\end{array}$ & Percent \\
\hline Alabama & 217,203 & 91,965 & $42 \%$ & 110,518 & 61,833 & $56 \%$ & 106,685 & 30,132 & $28 \%$ \\
\hline Alaska & 38,420 & 22,037 & $57 \%$ & 19,732 & 11,882 & $60 \%$ & 18,688 & 10,155 & $54 \%$ \\
\hline Arizona & 321,634 & 126,219 & $39 \%$ & 164,237 & 73,839 & $45 \%$ & 157,397 & 52,380 & $33 \%$ \\
\hline Arkansas & 138,428 & 49,807 & $36 \%$ & 70,145 & 30,987 & $44 \%$ & 68,283 & 18,820 & $28 \%$ \\
\hline California & $1,965,168$ & 777,545 & $40 \%$ & $1,008,790$ & 456,317 & $45 \%$ & 956,378 & 321,228 & $34 \%$ \\
\hline Colorado & 246,051 & 130,891 & $53 \%$ & 125,626 & 72,667 & $58 \%$ & 120,425 & 58,214 & $48 \%$ \\
\hline Connecticut & 170,245 & 118,067 & $65 \%$ & 87,460 & 61,667 & $71 \%$ & 82,785 & 49,390 & $60 \%$ \\
\hline Delaware & 38,022 & 27,684 & $73 \%$ & 19,209 & 15,634 & $81 \%$ & 18,813 & 12,060 & $64 \%$ \\
\hline $\begin{array}{l}\text { District of } \\
\text { Columbia }\end{array}$ & 17,577 & 3,440 & $20 \%$ & 8,527 & 2,178 & $26 \%$ & 9,050 & 1,262 & $14 \%$ \\
\hline Florida & 799,602 & 243,397 & $30 \%$ & 406,066 & 138,969 & $34 \%$ & 393,536 & 104,428 & $27 \%$ \\
\hline Georgia & 481,043 & 193,722 & $40 \%$ & 243,352 & 116,779 & $48 \%$ & 237,691 & 76,943 & $32 \%$ \\
\hline Hawaii & 51,069 & 33,735 & $66 \%$ & 26,440 & 19,842 & $75 \%$ & 24,629 & 13,893 & $56 \%$ \\
\hline Idaho & 82,631 & 45,148 & $55 \%$ & 42,395 & 26,100 & $62 \%$ & 40,236 & 19,058 & $47 \%$ \\
\hline Illinois & 624,679 & 339,944 & $54 \%$ & 318,519 & 200,270 & $63 \%$ & 306,160 & 139,674 & $46 \%$ \\
\hline Indiana & 316,329 & 152,577 & $48 \%$ & 160,244 & 91,094 & $57 \%$ & 156,085 & 61,483 & $39 \%$ \\
\hline Iowa & 144,784 & 140,939 & $97 \%$ & 74,607 & 83,584 & $100 \%+$ & 70,177 & 57,355 & $82 \%$ \\
\hline Kansas & 137,855 & 103,649 & $75 \%$ & 70,639 & 62,547 & $89 \%$ & 67,216 & 41,102 & $61 \%$ \\
\hline Kentucky & 193,961 & 99,233 & $51 \%$ & 99,424 & 53,919 & $54 \%$ & 94,537 & 45,314 & $48 \%$ \\
\hline Louisiana & 186,111 & 100,405 & $54 \%$ & 92,907 & 60,961 & $66 \%$ & 93,204 & 39,444 & $42 \%$ \\
\hline Maine & 57,815 & 53,634 & $93 \%$ & 29,732 & 28,858 & $97 \%$ & 28,083 & 24,776 & $88 \%$ \\
\hline Maryland & 256,836 & 125,431 & $49 \%$ & 130,635 & 71,798 & $55 \%$ & 126,201 & 53,633 & $42 \%$ \\
\hline Massachusetts & 287,506 & 221,628 & $77 \%$ & 145,832 & 124,467 & $85 \%$ & 141,674 & 97,161 & $69 \%$ \\
\hline Michigan & 492,272 & 304,438 & $62 \%$ & 251,729 & 174,429 & $69 \%$ & 240,543 & 130,009 & $54 \%$ \\
\hline Minnesota & 262,041 & 230,421 & $88 \%$ & 134,437 & 120,109 & $89 \%$ & 127,604 & 110,312 & $86 \%$ \\
\hline
\end{tabular}

Journal of Amateur Sport Special Issue: Political Economy Buchanan et al., 2016 


\begin{tabular}{|c|c|c|c|c|c|c|c|c|c|}
\hline Mississippi & 133,809 & 110,417 & $83 \%$ & 66,753 & 66,756 & $100 \%+$ & 67,056 & 43,661 & $65 \%$ \\
\hline Missouri & 270,370 & 172,722 & $64 \%$ & 138,658 & 103,745 & $75 \%$ & 131,712 & 68,997 & $52 \%$ \\
\hline Montana & 42,089 & 31,746 & $75 \%$ & 21,752 & 17,902 & $82 \%$ & 20,337 & 13,844 & $68 \%$ \\
\hline Nebraska & 88,073 & 77,107 & $88 \%$ & 45,371 & 45,894 & $100 \%+$ & 42,702 & 31,213 & $73 \%$ \\
\hline Nevada & 131,953 & 43,471 & $33 \%$ & 67,043 & 26,092 & $39 \%$ & 64,910 & 17,379 & $27 \%$ \\
\hline $\begin{array}{l}\text { New } \\
\text { Hampshire }\end{array}$ & 60,805 & 44,434 & $73 \%$ & 31,408 & 23,833 & $76 \%$ & 29,397 & 20,601 & $70 \%$ \\
\hline New Jersey & 400,875 & 270,423 & $67 \%$ & 202,954 & 158,052 & $78 \%$ & 197,921 & 112,371 & $57 \%$ \\
\hline New Mexico & 97,242 & 47,571 & $49 \%$ & 49,821 & 26,247 & $53 \%$ & 47,421 & 21,324 & $45 \%$ \\
\hline New York & 825,972 & 389,475 & $47 \%$ & 419,073 & 215,447 & $51 \%$ & 406,899 & 174,028 & $43 \%$ \\
\hline $\begin{array}{l}\text { North } \\
\text { Carolina }\end{array}$ & 438,375 & 210,186 & $48 \%$ & 223,725 & 124,299 & $56 \%$ & 214,650 & 85,887 & $40 \%$ \\
\hline North Dakota & 30,116 & 25,291 & $84 \%$ & 15,401 & 14,681 & $95 \%$ & 14,715 & 10,610 & $72 \%$ \\
\hline Ohio & 518,617 & 327,919 & $63 \%$ & 264,139 & 194,330 & $74 \%$ & 254,478 & 133,589 & $52 \%$ \\
\hline Oklahoma & 176,812 & 99,794 & $56 \%$ & 90,288 & 56,593 & $63 \%$ & 86,524 & 43,201 & $50 \%$ \\
\hline Oregon & 178,239 & 98,638 & $55 \%$ & 91,848 & 56,915 & $62 \%$ & 86,391 & 41,723 & $48 \%$ \\
\hline Pennsylvania & 557,464 & 315,492 & $57 \%$ & 285,823 & 169,198 & $59 \%$ & 271,641 & 142,294 & $52 \%$ \\
\hline Rhode Island & 44,672 & 28,854 & $65 \%$ & 22,838 & 16,567 & $73 \%$ & 21,834 & 12,287 & $56 \%$ \\
\hline $\begin{array}{l}\text { South } \\
\text { Carolina }\end{array}$ & 208,648 & 96,465 & $46 \%$ & 107,071 & 61,436 & $57 \%$ & 101,577 & 35,029 & $34 \%$ \\
\hline South Dakota & 37,267 & 28,052 & $75 \%$ & 19,122 & 16,195 & $85 \%$ & 18,145 & 11,857 & $65 \%$ \\
\hline Tennessee & 281,971 & 107,075 & $38 \%$ & 143,739 & 68,795 & $48 \%$ & 138,232 & 38,280 & $28 \%$ \\
\hline Texas & $1,387,513$ & 798,333 & $58 \%$ & 711,511 & 484,030 & $68 \%$ & 676,002 & 314,303 & $46 \%$ \\
\hline Utah & 169,077 & 59,134 & $35 \%$ & 87,050 & 35,011 & $40 \%$ & 82,027 & 24,123 & $29 \%$ \\
\hline Vermont & 27,557 & 14,719 & $53 \%$ & 14,214 & 8,049 & $57 \%$ & 13,343 & 6,670 & $50 \%$ \\
\hline Virginia & 375,975 & 174,518 & $46 \%$ & 193,085 & 101,081 & $52 \%$ & 182,890 & 73,437 & $40 \%$ \\
\hline Washington & 327,134 & 164,998 & $50 \%$ & 168,204 & 93,918 & $56 \%$ & 158,930 & 71,080 & $45 \%$ \\
\hline West Virginia & 80,673 & 36,091 & $45 \%$ & 41,302 & 21,079 & $51 \%$ & 39,371 & 15,012 & $38 \%$ \\
\hline Wisconsin & 265,682 & 192,400 & $72 \%$ & 136,544 & 113,020 & $83 \%$ & 129,138 & 79,380 & $61 \%$ \\
\hline Wyoming & 26,243 & 19,286 & $73 \%$ & 13,439 & 10,949 & $81 \%$ & 12,804 & 8,337 & $65 \%$ \\
\hline Total & $14,710,505$ & $7,713,577$ & $52 \%$ & $7,513,378$ & $4,490,854$ & $60 \%$ & $7,197,127$ & $3,222,723$ & $45 \%$ \\
\hline
\end{tabular}

Journal of Amateur Sport Special Issue: Political Economy Buchanan et al., 2016 